\title{
Modernising the Law on the Unlawful Treatment of Dead Bodies
}

\author{
Graham McBain ${ }^{1,2}$ \\ ${ }^{1}$ Peterhouse, Cambridge, UK \\ ${ }^{2}$ Harvard Law School, USA \\ Correspondence: Graham McBain, 21 Millmead Terrace, Guildford, Surrey GU2 4AT, UK. E-mail: \\ gsmcbain@aol.com
}

Received: June 7, 2014 Accepted: August 9, 2014 Online Published: August 25, 2014

doi:10.5539/jpl.v7n3p89 URL: http://dx.doi.org/10.5539/jpl.v7n3p89

\begin{abstract}
It is important that English law be up-to-date - as well reflect modern social realities. However, in many areas, English law is badly out of date. This is particularly so in the field of English criminal law where a number of common law offences still exist of an uncertain, and confused, nature.

The purpose of this article is to argue for the abolition of the common law offence of the unlawful treatment of a dead body (itself, comprising a number of discrete offences). It is asserted this offence should now be clarified in legislation. Further, it should not be contained in criminal legislation. Rather, it should be placed in legislation relating to burial. This is more appropriate. It also makes the same more accessible to laymen and experts in this area.
\end{abstract}

Keywords: unlawful treatment of dead bodies, leaving a corpse unburied, preventing the burial of a corpse, removing a corpse from a grave, obstructing a coroner's inquest, outraging public decency, creating a new, statutory, offence of the unlawful treatment of a corpse.

\section{INTRODUCTION}

One of the problems relating to the modernisation of English criminal law is that - apart from the need for the consolidation of legislation relating to the same ${ }^{1}$ - there still exist a number of common law criminal offences. These are sustained by reference to an antiquated caselaw. However, this caselaw is usually wholly inappropriate to the modern society in which we live. As a result, it would be beneficial to the legal system and help reduce unnecessary cases coming before the English courts, to review all these common law offences.

The purpose of this article is to review the criminal law with regard to one of these common law offences - the unlawful treatment of dead bodies. The common law still regulates much of this field of law and this article argues that such matters should now be encapsulated in legislation. Further, it is asserted these offences should not be placed in legislation dealing with the general criminal law. Instead, it should be consolidated with other (mainly Victorian) legislation which relates to the burial of the dead and cemeteries since such is an appropriate place for it, in order to facilitate easier consultation.

When considering common law offences relating to the unlawful treatment of dead bodies it may be noted from the outset - that most legal texts on criminal law - both early ${ }^{2}$ and modern ${ }^{3}$ - scarcely deal with them.

\footnotetext{
${ }^{1}$ GS McBain, Our Criminal Law should only be 200 Years out of Date (2014) Rev Euro Studies, vol 6, no 2.

${ }^{2}$ For older texts pre-1955, see Sweet \& Maxwell, A Legal Bibliography of the British Commonwealth of Nations (Sweet \& Maxwell, 1955, vol 2 (criminal law). Of note are: SF Harris, Principles of the Criminal Law $\left(1^{\text {st }} \mathrm{ed}, 1877\right)$ and Russell on Crimes and Misdemeanors $\left(4^{\text {th }}\right.$ ed, 1865).

${ }^{3}$ See, for example: (a) C McAlhone \& R Huxley-Binns, Criminal Law.The Fundamentals (3rd ed, 2013); (b) MJ Allen, Textbook on Criminal Law (12 ${ }^{\text {th }}$ ed, 2013); (c) A Ashworth \& J Horder, Principles of Criminal Law (7 ${ }^{\text {th }}$ ed, 2013); (d) Blackstone, Criminal Practice (23 $3^{\text {rd }}$ ed, 2013); (e) R Card et al, Criminal Law (20 $0^{\text {th }}$ ed, 2012); (f) CMV Clarkson \& HM Keating, Criminal Law, Text and Materials $\left(7^{\text {th }}\right.$ ed, 2010); (g) C Elliott \& F Quinn, Criminal Law ( ${ }^{\text {th }}$ ed, 2010); (h) R Heaton, Criminal Law (2 ${ }^{\text {nd }}$ ed, 2006); (i) J Herring, Criminal Law ( ${ }^{\text {th }}$ ed 2013); (j) M Jefferson, Criminal Law (9 $9^{\text {th }}$ ed, 2009); (k) Lacey, Wells \& Quick, Reconstructing Criminal Law. Text and Materials (4 $4^{\text {th }}$ ed, 2010); (1) J Loveless, Complete Criminal Law. Text. Cases and Materials ( $3^{\text {rd }}$ ed, 2012); (m) N Padfield, Criminal Law (7 $7^{\text {th }}$ ed, 2010); (n) A Reed \& B Fitzpatrick, Criminal Law $\left(4^{\text {th }}\right.$ ed, 2009); (o) AP Simester, Simester \& Sullivan's Criminal Law: Theory and Doctrine (5 $5^{\text {th }}$ ed, 2013); (p) D Ormerod, Smith \& Hogan's Criminal Law (13 ${ }^{\text {th }}$ ed, 2011); (q) DJ Baker, Glanville Williams Textbook of Criminal Law ( $3^{\text {rd }}$ ed, 2012); (r) MJ Allen \& S Cooper, Elliott \& Woods' Cases and Materials on Criminal Law (11 ${ }^{\text {th }}$ ed, 2013); (s) M Molan, Cases and Materials
} 
Archbold, Blackstone and Halsbury do. However, only to a limited extent. This reflects, in part, the lack of caselaw and legal analysis in this area of criminal law. ${ }^{4}$ Although there are some legal texts devoted to the subject of burial, ${ }^{5}$ these are now out of date. They also tend to cover the logistics of burial - as opposed to crimes in connection with it.

\section{OFFENCES RELATING TO DEAD BODIES}

Probably the best modern summary of the law in this area is contained in Archbold's Criminal Pleading, Evidence and Practice (2014). Archbold states the following, by way of introduction to these crimes, which it covers as an aspect of the common law offence of public (common) nuisance: ${ }^{6}$

The offences dealt with in the ensuing paragraphs are particular common law offences, rather than the species of the common law offence of nuisance, although conduct in relation to a dead body has been held to constitute a nuisance, as where a dead body was burnt in such a place and manner as to annoy persons passing alone public roads or other places where they had a right to go ${ }^{7}$...or where the naked body of a dead child was exposed in or near, and within view of, the highway...

Archbold then considers the law with regard to four categories of unlawful treatment, viz: ${ }^{9}$

- $\quad$ Leaving a corpse unburied (inc. preventing burial);

- Disposing of a corpse;

- Removing a corpse from a grave;

- Obstructing a coroner.

To this should be added another category which has been upheld by the courts pursuant to the common law offence of 'outraging public decency.' This is, effectively, the dis-respectful treatment of a foetus or embryo. ${ }^{10}$ It is asserted that this offence should also be reflected in modern legislation dealing with the unlawful treatment of corpses.

\section{EARLY LAW}

Early legal commentators had little to say with regard to the unlawful treatment of dead bodies. Thus, there is scant reference in the following texts:

- $\quad$ W Staunford, Pleas of the Crown (1557); ${ }^{11}$

- $\quad$ M Dalton, The Countrey Justice (1619); ${ }^{12}$

- $\quad$ E Coke, Institutes of the Laws of England (1628-41); ${ }^{13}$

- W Hawkins, A Treatise of the Pleas of the Crown (1716-1824); ${ }^{14}$

- $\quad$ M Hale, The History of the Pleas of the Crown (published 1736, written 1640's); ${ }^{15}$

on Criminal Law (4 $4^{\text {th }}$ ed, 2008); (t) J Martin \& T Storey, Unlocking Criminal Law (3 $3^{\text {rd }}$ ed, 2010); (u) P Hungerford-Welch \& A Taylor, Sourcebook on Criminal Law (1997); (v) M Molan et al, Bloy \& Parry's Principles of Criminal Law (4 ${ }^{\text {th }}$ ed, 2000); (w) W Wiilson, Criminal Law $\left(4^{\text {th }}\right.$ ed, 2011). For older $20^{\text {th }}$ century texts, see JW Cecil Turner, Russell on Crime $\left(12^{\text {th }}\right.$ ed, 1964); JW Cecil Turner, Kenny's Outlines of Criminal Law (19 $9^{\text {th }}$ ed, 1966) and R Cross \& PA Jones, An Introduction to Criminal Law ( ${ }^{\text {nd }}$ ed, 1949).

${ }^{4}$ Archbold, Criminal Pleading, Evidence and Practice (Sweet \& Maxwell. London, 2014); Archbold, Magistrates Courts Criminal Procedure ('Archbold Procedure'); Blackstone's Criminal Practice 2013 (eds A Hooper \& D Ormerod) and Halsbury, Laws of England ( $5^{\text {th }}$ ed with updates).

${ }^{5}$ E Austin, Burial Grounds and Cemeteries (1907), T Baker, Laws relating to Burials $\left(6^{\text {th }}\right.$ ed, 1901), A Fellows, Law of Burial (2 $2^{\text {nd }}$ ed, 1952), JB Little, Law of Burials (3 ${ }^{\text {rd }}$ ed, 1902), CJ Polson et al, The Disposal of the Dead ( $3^{\text {rd }}$ ed, 1975 - a useful work), ES Watkins, Laws of Burials and Burial Grounds (1948), WG Glen, The Law relating to Burial and the Dead (1844, $4^{\text {th }}$ ed). See also MR Davies \& DA Smale, Davies' Law of Burial, Cremation and Exhumation ( $7^{\text {th }}$ ed, 2002). Also, Ministry of Justice, Burial Law and Policy in the 21 $1^{\text {st }}$ Century: The Way Forward (June 2007, Government Response to the Consultation carried out by the Home Office/DCA) ('MOJ-2007').

${ }^{6}$ Archbold, n 4, paras 31-54 to 59 .

${ }^{7}$ It cites $R v$ Price (1884) 12 QBD 247, see 3.

${ }^{8}$ See $R v$ Clark (1883) 15 Cox 171, see 4.

${ }^{9}$ I leave aside the statutory offence of sexual penetration of a corpse, see Sexual Offences Act 2003, s 70.

${ }^{10} R v$ Gibson (1990), see 9.

${ }^{11}$ W Staunford, Les Plees del Coron (Richard Tottell,1557).

${ }_{12}$ M Dalton, The Countrey Justice (London, Society of Stationers, 1619).

${ }^{13} \mathrm{E}$ Coke, Institutes of the Laws of England (W Clarke \& Sons, London, last ed, 1824).

${ }^{14}$ W Hawkins, A Treatise of the Pleas of the Crown (printed for E \& R Nutt \& R Gosling, 1716-21). This text cites the $3^{\text {rd }}$ ed, published in 1739. The last edition (the $8^{\text {th }}$ ed) was published in 1824 . 
- W Blackstone, Commentaries on the Laws of England (1765-9); ${ }^{16}$

- $\quad$ WH East, A Treatise of the Pleas of the Crown (1803); ${ }^{17}$

- W Archbold, Criminal Pleading, Evidence and Practice (1822-2014). ${ }^{18}$

However, Russell - in the first edition of his work On Crimes and Misdemeanors written in 1819 - contains a useful (albeit short) chapter on offences relating to dead bodies. ${ }^{19}$ It will be referred to in this article, where appropriate. Further, JF Stephen, in A Digest of the Criminal Law: Crimes and Punishments (1883) provides a useful summary of the law by reference to an article of legislation which he proposed be enacted. ${ }^{20}$ Finally, the last edition of Russell (edited by Turner in 1964) contains a more recent statement of the law in this area. ${ }^{21}$ Given that the legislation which Russell referred to in 1819 has been repealed, a useful case to commence with on this subject is Price (1884) ${ }^{22}$ in which Stephen J considered the law on the disposal of dead bodies other than by way of burial.

- The case held that to burn (ie. cremate) a corpse was not a misdemeanor if it was so done so as to amount to a public nuisance, ${ }^{23}$

- Also, if an inquest was held in respect of a corpse, Stephen $J$ held that it was a misdemeanour to dispose of the corpse in order to the prevent the coroner from holding an inquest.

Thus, Price established the following:

- $\quad$ Cremation. The burning (cremation) of the dead - as opposed to burial - was not unlawful. ${ }^{24}$ This was later reflected in the Cremation Act 1902 (still extant); $;^{25}$

- Anatomy. The giving of a corpse for anatomy (that is, medical dissection) was also not unlawful; ${ }^{26}$

- $\quad$ Place of Cremation. To burn a corpse in a public place so as to annoy persons was a public nuisance. ${ }^{27}$

As it is, today, cremation is more widely practised than burial (it takes place in respect of more than $73 \%$ of deaths in England and Wales). ${ }^{28}$ Further, the following may be noted:

\footnotetext{
${ }^{15}$ M Hale, The History of the Pleas of the Crown (printed for E \& R Nutt \& R Gosling, 1736).

${ }^{16}$ W Blackstone, Commentaries on the Laws of England.(Oxford, Clarendon Press, $1^{\text {st }}$ ed, 1765-9, University of Chicago Press rep 1979).

${ }^{17}$ EH East, $A$ Treatise of the Pleas of the Crown (London, A Strahan, 1803). See $\mathrm{p} 652$ (larceny of a corpse).

18 JF Archbold, A Summary of the law relative to Pleading and Evidence in Criminal Cases (London, 1822) and Archbold, $\mathrm{n} 4$.

19 WO Russell, A Treatise on Crimes and Misdemeanors ( $1^{\text {st }}$ ed, 1819), ch 40, pp 606-9. The last edition of Russell was edited by Turner in 1964 (see n 3). In compiling his text in 1819 he referred (as he states in the preface) to Hale (see n 15), Hawkins (see n 14), M Foster, Crown Cases ( $1^{\text {st }}$ ed 1762, last ed ( $3^{\text {rd }}$ ed), 1809), Blackstone (see $\left.\mathrm{n} 16\right)$, East (see $\left.\mathrm{n} 17\right)$ and T Leach, Cases in Crown Law [1730-1815] (1 $1^{\text {st }}$ ed, 1789, last ed ( $4^{\text {th }}$ ed), 1815).

${ }^{20}$ JF Stephen, A Digest of the Criminal Law (3 ${ }^{\text {rd }}$ ed, Macmillan 1883), art 175.

${ }^{21}$ See $\mathrm{n} 3$ (Russell, 1964 ed), ch 96.

${ }^{22} R v$ Price (1884) 12 QBD 247. See also Polson, n 5, p 39. Dr Price was a doctor who refused to register the death of his son (who died from natural causes). He then sought to cremate him. His trial was at Cardiff Assize in February 1884. He was acquitted on both charges. As a result, the Cremation Society offered facilities for cremation at Woking, Surrey and the first cremation took place on 26 March 1885 . The regulations of the Society became the basis of the Cremation Act 1902 (and regulations thereunder).

${ }^{23} \mathrm{Ibid}$, per Stephen J at p 254 'I am of opinion that a person who burns instead of burying a dead body does not commit a criminal act, unless he does it in such a manner as to amount to a public nuisance at common law.' See also the observations of Lord Stowell in Gilbert v Buzzard on burial and cremation, see $\mathrm{n} 44$.

${ }^{24}$ Ibid, p 249 'the burning of the dead has never been formally forbidden or even mentioned or referred to, so far as I know, in any part of our law.' Also, p 256 'I think that to burn a dead body decently or inoffensively is not criminal, it is obvious that if so done in such a manner as to be offensive to others it is a nuisance of an aggravated kind.'

${ }^{25}$ See $R$ v Hunter [1974] QB 95 at p 98 per Cairns LJ. Harris, n 2, p 222 'The burning of dead bodies is governed by the Cremation Act 1902 , which expressly provides that nothing therein contained shall authorise the creation or commission of a nuisance. By this Act provisions were made enabling burial authorities to construct crematoria, for the maintenance and inspection of which regulations have been made.' See also Russell, n 3, vol 2, p 1418 and Polson, n 5, ch 1. Also, Cremation Act 1902, s 8 (penalties for breach of the regulations).

${ }^{26} R v$ Price (1884) 12 QBD 247 at $\mathrm{p} 252$ 'The practice of anatomy is lawful and useful though it may involve an unusual means of disposing of dead bodies.' See also Russell, n 3, vol 2, pp 1418-20 and Polson, n 5, ch 3.

${ }^{27}$ Ibid, p 256 'To burn a dead body in such a place and such a manner as to annoy persons passing along public roads or other places where they have a right to go is beyond all doubt a nuisance, as nothing more offensive both to sight and to smell can be imagined.' See also $R v$ Byers (1907) 71 JP 205 (guilty of misdemeanour in disposing of a corpse with intent to obstruct a coroner's inquest) and Russell, n 3, vol 2, pp 1418.

${ }^{28}$ Cemetery Research Group, University of York (2010 data). The figure in 2013 is thought to be more than $75 \%$. See also Ministry of Justice, Cremation Regulations: Consolidation and Modernisation: Consultation Paper (2007).
} 
- Medical Science. Today, many people in the UK dedicate their bodies to medical science (often called medical donation or body donation). This is for anatomical examination, research, education and training. ${ }^{29}$ Also, for the transplant of human tissue and organs or for public display. ${ }^{30}$ Pursuant to the Human Tissue Act 2004 written (and witnessed) consent must be given by the donor for such donation prior to death; 31

- $\quad$ Other Practices. As to practices (now rare) in other countries to:(a) expose a body to decay, or for carrion to consume it or; (b) to place it in a river, ${ }^{32}$ this would be an offence under English common law, that of unlawfully leaving a corpse unburied, for which see below.

\section{LEAVING A CORPSE UNBURIED ${ }^{33}$}

As to leaving a corpse unburied, in Clark (1883) ${ }^{34}$ the dead (naked) corpse of a child (which was subsequently mutilated) ${ }^{35}$ was placed on a foot pavement near the back door of a house in a back street towards the outside of the suburbs in West Hartlepool. It had been placed there by its mother.

- Although she was not held responsible for the mutilation and she was not charged with murder or the concealment of a corpse, ${ }^{36}$ the jury found that: (a) the place where the body had been put was one where many people were certain to pass and re-pass; and (b) the 'exposure was calculated to shock and disgust the passers-by and outrage public decency'. ${ }^{37}$

For its part, the 2014 edition of Archbold states:

To leave unburied the corpse of a person for whom the defendant was bound to provide 'Christian burial' (which probably means only 'decent burial') ${ }^{38}$ such as a wife or child is an indictable offence, if he is shown to have had the ability to provide such burial. ${ }^{39}$

Reference is made by Archbold to the following cases:

- $\quad$ Vann (1851). ${ }^{40}$ This case held that a person without the means of providing burial for a deceased child was not liable to be indicted for a misdemeanor in not so providing - even though a nuisance was occasioned by allowing the body to remain unburied and even though the poor law authorities of the union had offered the parent a loan to defray burial expenses - since the person was not bound under such circumstances to contract a debt.

In this case, Campbell CJ stated: 'It is true that a man is bound to give a Christian burial to his deceased child, if he has the means of doing so; but he is not liable to be indicted for a nuisance, if he has not the means of providing burial for it. He cannot sell the body, put it into a hole, or throw it into the river; but unless he has the means of giving the body Christian burial, he is not liable to be indicted, even though a nuisance may be occasioned by leaving the body unburied, for which the parish officer

\footnotetext{
29 The Anatomy Act 1984 has been replaced by the Human Tissue Act 1984.

${ }^{30}$ See Human Tissue Act 2004, sch 1 (purposes requiring consent: general).

31 Human Tissue Act 2004,ss 2 \& 3 (consent of adults and children).

32 See the comment of Campbell CJ in Vann, for which see text to n 42. See also Polson, n 5, ch 1 (he discusses, inter alia, disposal by exposure, artificial decomposition, cannibalism, mummification, refrigeration, embalming, water and ship burial). See also $\mathrm{J}$ Paterson, Commentaries on the Liberty of the Subject and the Laws of England relating to the Security of the Person (Macmillan \& Co, 1877), vol 2, ch 14.

${ }^{33}$ In earlier times, the bodies of executed felons were often hung on gibbets until they rotted and, in the case of those who had committed high treason, they were drawn, hung and quartered with their bodies then being exposed (usually on castle ramparts) for the edification of the general public. This no longer occurs (the death penalty also having been abolished for all offences). In the case of suicides, they were often buried at crossroads with a stake through them. This also no longer occurs. See generally, W Eden, Principles of Penal Law ( ${ }^{\text {nd }}$ ed, 1771), pp 79-82 (of the disposal of the dead body of the criminal). See also Blackstone, n 16, vol 4, p 190.

${ }^{34} R v$ Clark (1883) 15 Cox 171.

35 The arms had been severed and the face and upper part of the body had been flayed.

${ }^{36}$ It seems the jury accepted the assertion of the mother that the child had been stillborn.

37 The months was sentenced to 6 months imprisonment without hard labour for a public nuisance, viz. the exposure of a dead body in a public highway.

${ }^{38}$ This appears to have come from the observation of Stephen, see n 20, p 118, n 2 'This can hardly be a duty in the case of persons who are not Christians, but probably 'Christian' means only decent.' See also Russell, n 3, vol 2, p 1416 and the Burial Laws Amendment Act 1880. See also Polson, n 5, p 47.

39 Archbold, n 4, para 31-55.

${ }^{40} R v$ William Vann, 2 Den 325(169 ER 523). See also Stephen, n 20, p 119 and Polson, n 5, p 52.
} 
would probably be liable. ${ }^{41}$ It has been contended that the prisoner was bound to incur a debt, and thereby take away the means of maintaining his family. We are all of opinion that he was not bound to accept the loan on the terms offered proposed to him and thus to contract a debt which would render him liable to be proceeded against, and to lose his liberty. ${ }^{42}$

- $\quad$ Stewart (1840). ${ }^{43}$ This case held that the overseers of a parish were not bound to bury the body of a pauper lying in the parish but in not a parochial house. This was even though the pauper was a married woman whose husband was settled in the parish and receiving relief there.

In this case, Denman CJ stated: 'Every person dying in this country, and not within certain exclusions laid down by the ecclesiastical law, has a right to Christian burial, and that implies the right to be carried from the place where his body lies to the parish cemetery. Further, to use the words of Lord Stowell in Gilbert $v$ Buzzard... 44 'That bodies should be carried in a state of naked exposure to the grave, would be a real offense to the living, as well as an apparent indignity to the dead.' We have no doubt, therefore, that the common law casts on someone the duty of carrying to the grave, decently covered, the dead body of any person dying in such a state of indigence as to leave no funds for that purpose. The feelings and the interests of the living require this, and create the duty: but the question is, on whom it falls. It is enough for the disposal of this rule to say that it is not cast upon the overseers, where the death does not take place under the roof of any parish house, or that which, under the circumstances can be considered as such...It would seem that the individual under whose roof a poor person dies is bound to carry the body decently covered to the place of burial: he cannot keep him unburied, nor do any thing which prevents Christian burial: he cannot therefore cast him out, so as to expose the body to violation, or to offend the feelings or endanger the health of the living: and, for the same reason, he cannot carry him uncovered to the grave. It will probably be found, therefore, that, where a pauper dies in any parish house, poor house, or union house, that circumstance casts on the parish or union, as the case may be, to bury the body: not by virtue of the Statute of Elizabeth, ${ }^{45}$ but on the principles of the common law.'

- Jenkins v Tucker (1788). ${ }^{46}$ Where a husband goes abroad (in this case, Jamaica) and leaves his wife, who dies in his absence, a third person (in this case, the father) who voluntarily pays the expenses of her funeral - suitable to the rank and fortune of the husband, though without the knowledge of the husband - may recover from him the money so laid out, especially if such third person be the father of the wife.

In this case, Lord Loughborough stated 'I think there was a sufficient consideration to support this action for the funeral expenses, though there was neither request nor consent on the part of the defendant, for the plaintiff acted in discharge of a duty which the defendant was under a strict legal necessity of herself performing, and which common decency required at his hands; the money therefore which the plaintiff paid on this account; was paid to the use of the defendant.' 47 And Wilson J stated 'the plaintiff having defrayed the expenses of the funeral, the husband is in justice, equally liable to repay those expenses, and in him the law will imply an assumpsit for that purpose.' 48

These cases, therefore, provide the following:

- A parent does not commit an offence in not burying a child if without means (Vann). Nor are the overseers of a parish responsible where the corpse is not in a parochial house (Stewart). Further, a third party (especially, a father) can recover against a husband, for burial costs (Jenkins v Tucker);

- As to who is legally responsible for burial, a father (or mother) is responsible for the burial of a child (Vann), if with means. An individual under whose roof a poor person dies is also bound to carry the body - decently covered - to a place of burial (Stewart).

\footnotetext{
${ }^{41}$ Reference was made to 7 \& 8 Vict, c 101, s 31 (1844, rep).

${ }^{42}$ At $\mathrm{p} 330$.

${ }^{43} R v$ Stewart and Another 12 A \& E 773 (113 ER 1007) at 778. See also Russell, n 3, vol 2, p 1417 and Paterson, n 32, vol 2, p 431.

442 Hagg, Consistory Reports (161 ER 761) 333, 344.

45 See Poor Law Act 1601, 43 Eliz 1, c 2 (rep).

$461 \mathrm{H} \mathrm{Bl} 90$ (126 ER 55). For other cases as to the disposal appropriate to the estate of the deceased see Polson, n 5, pp 49-50.

47 At 93.

${ }^{48}$ At $\mathrm{p} 94$.
} 
Russell (writing in 1964) stated it thus:

It is the duty of executors of the deceased to bury him if there are funds. It is the duty of a husband to bury his wife. ${ }^{49}$

While this is correct, it fails to include reference to: (a) the obligation of parents; and (b) others under whose roof the corpse is located. It is asserted that legislation should expressly provide for this position. See 10.

\section{PREVENTING THE BURIAL OF A CORPSE}

There is no property in a corpse. ${ }^{50}$ However, Archbold notes that:

It is also an indictable offence to prevent the burial of a corpse.

Reference is made to Russell as well as to the cases of Lynn $(1788)^{51}$ and Hunter (1974). ${ }^{52}$ As to these:

- $\quad \underline{\operatorname{Lynn}(\mathbf{1 7 8 8}){ }^{53}}$ This case was designed to put an end to the practice of grave robbing in order to supply bodies for dissection. The defendant was convicted on an indictment charging him with entering a burial ground and unearthing a coffin from which he extracted a corpse which he took away for the purpose of dissection. The case noted that the common law did not - it appear - as yet make this a criminal offence. ${ }^{54}$ Counsel referred to Lord Coke. ${ }^{55}$

The case states that 'The court said that common decency required that the practice should be put a stop to. That the offence was cognizable in a criminal court, as being highly indecent, and contra bonos mores; at the bare idea alone of which nature revolted. That the purpose of taking up the body for dissection did not make it less an indictable offence...But inasmuch as the defendant might have committed a crime merely from ignorance, no person having been punished in this court for this offence, they only fined him 5 marks; ${ }^{, 56}$

- Young (pre-1788). The master of a London workhouse, a surgeon and another person were indicted for a conspiracy to prevent the burial of a person who had died in a workhouse, ${ }^{57}$

- $\quad$ Cundick (1822)..$^{58}$ A jail handed over the corpse of an executed convict for burial to an undertaker. Instead of burying it, he sold it for dissection. He was held to have committed a misdemeanour at common law;

${ }^{49}$ Russell, n 3, vol 2, p 1416.

${ }^{50}$ East (writing in 1802), n 17, vol 2, p 652 'There can be no property in a dead corpse; and therefore stealing it is no felony, but a very high misdemeanor'. East refers to the case of Dr Handyshire (trover brought against him for co-joined twins' corpse). Willes CJ held the action would not lie. Cf. there is property in a shroud and in the coffin (see cases cited by East and n 51). See also Russell, n 3, vol 2, p 1413.

${ }^{51} 2$ TR 733 (100 ER 394). See also 1 Leach 497 (168 ER 350 ).

${ }^{52} R v$ Hunter [1974] QB 95.

${ }^{53}$ For the form of the indictment see Archbold (1822 ed), n 4, p 380. For the practice of grave robbing, see JB Bailey, The Dairy of a Resurrectionist 1811-1812 (London, 1896) and Polson, n 5, p 62.

${ }^{54}$ It noted that 1 Jac 1 c $12(1603$, rep 9 Geo 2 c 5, 1735) made it a felony to steal a dead body for the purpose of witchcraft. See also Hawkins ( $3^{\text {rd }}$ ed, 1739), vol 1, pp 5-6 (felony to take up a corpse or any part to be used in any manner of witchcraft). Coke, n 13, vol 3, p 44 refers to a person who was arrested in Southwark, London. He had with him the head and face of a dead man as well as a book of sorcery. The man was brought into the king's bench. However, no indictment was preferred against him and the only crime imputed to him was that of being a sorcerer. Coke indicates that the case was held before Knevett (Knyvet) CJ (he was CJ from 1365-72).

${ }^{55}$ Coke, n 13, vol 3, p 203 'It is to be observed that in every sepulchre, that has a monument, two things are to be considered, viz. the monument, and the sepulchre or burial of the dead; the burial of the cadaver (that is caro data vermibus) is nullius in bonis, and belongs to ecclesiastical cognizance; but as to the monument, action is given at the common law for defacing thereof.' (spelling modernised). For the stealing of a winding sheet (found guilty of petty larceny, he was whipped), see Haynes (Hains) Case (1613) referred to in Coke, n 13, vol 3, p 110 and 12 Co 113 (77 ER 1389)). See also Hale, n 15, vol 1, p 515 (larceny ) and Hawkins, n 14, vol 1, p 94 (larceny of a shroud). Blackstone, n 16, vol 4, p 236 stated: 'the stealing the corpse itself, which has no owner, (though a matter of great indecency) is no felony, unless some of the gravecloths be stolen with it. Also, p 429 'though the heir has a property in the monuments and escutcheons of his ancestors, yet he has none in their bodies and ashes; nor can he bring any civil action against such as indecently, at least, if not impiously, violate and disturb their remains, when dead and buried. The parson indeed, who has the freehold of the soil, may bring an action of trespass against such as dig and disturb it: and, if any one in taking up a dead body steals the shroud or other apparel, it will be felony; for the property thereof remains in the executor, or whoever was at the charge of the funeral.' See also Dalton, n 12, p 244 (refers to Nottingham 's Case (1617) re a winding sheet).

${ }^{56}$ See also Russell, n 19, p 606. Also, R v Feist (1858) D \& B 590 (169 ER 1132)(disposal of bodies for dissection. Anatomy Act 1832, s 7) and Russell, n 3, vol 2, p 1419-20.

57 The date of this case is not clear although in $R v$ Lynn, counsel (Garrow) referred to as a 'case of one Young a few years ago'.

${ }^{58} R v$ Cundick (1822) Dow \& Ry NP 13 (171 ER 900). See also Russell, n 3, vol 2, p 1414. 
- $\quad$ Scott (1842). ${ }^{59} \mathrm{~A}$ jailer refused to deliver up for burial the corpse of a prisoner who had died to his executors on the ground that he was owed money from the estate of the former. Maule J indicated that the notion of a jailer being authorised to detain a corpse on account of a debt was a mistake and that a jailer so doing was guilty of misconduct in his public office and liable to prosecution for the same; ${ }^{60}$

- $\quad$ Hunter (1974). The defendants went with a girl at night to a playing field where she died by accident. The defendants hid her body under a pile of stones where it remained hidden for 4 months. The defendants were convicted of conspiring to prevent the burial of a corpse. On appeal, it was held that it was a crime to prevent the proper burial of a corpse without lawful excuse, whether there was a duty to bury it or not. It was also held that the defendants were rightly convicted of a conspiracy to prevent such a burial notwithstanding that prevention of the burial was not the defendants' object when they hid the body. ${ }^{61}$

In this case Cairns J stated: ${ }^{62}$ 'conspiracy to prevent the burial of a corpse is not, so far as this court is aware, a charge that has ever been laid in modern times. It is however, stated in Russell ${ }^{63}$ that to prevent the burial of a dead body is an indictable misdemeanour and the authority cited is the unreported case of Rex $v$ Young. ${ }^{64}$ We see no reason to suppose that Russell is wrong in concluding that this is still an offence. It is pointed out on behalf of the defendants that Rex $v$ Young was a charge against the master of a workhouse where the person had died and another defendant. But if it is a crime for a person responsible for burial to prevent it, there is no reason for regarding the act of a stranger in preventing burial as any less reprehensible. We think that in this connection burial means lawful and decent burial. Clearly a crime would not be committed if a body were cremated, cremation now being authorised by the Cremation Act 1902. But if a decent burial is prevented without lawful excuse, we consider that this is an offence. If it is an offence to prevent burial, then it is an offence to conspire to prevent that burial. Indeed in Rex $v$ Young the indictment was for conspiracy...In our view the judge's direction that of the defendants agreed to conceal the body and the concealment in fact prevented burial, then the offence was made out, although prevention of burial was not the object of the agreement, was a correct direction in law. The appeal against that conviction is therefore dismissed.'

Further, in Skidmore (2009) ${ }^{65}$ it was held that the fact that the defendant (an undertaker) acted in panic - as opposed to some dishonest motive - did not mean that an offence had not been committed.

In conclusion, from the caselaw, preventing the burial of a corpse includes:

- Grave robbing (Lynn);

- Instead of burial, handling over the corpse for dissection - whether for profit or not (Cundick, Feist);

- Refusing to hand over a corpse until payment of an unpaid debt (Scott);

- Hiding a corpse (Hunter);

- Refusing, or neglecting, to perform a burial by those charged with that duty: Andrew $v$ Cawthorne (priest), Young (master of a workhouse).

It may be noted that - in modern times - the effects of cremation and the Human Tissue Act 2004 have effectively obviated the issues of grave robbing and unauthorised dissection. Further, workhouses no longer

\footnotetext{
${ }^{59} R v$ Scott (1842) 2 QB 248 (114 ER 97, case contained in a note to $R v$ Fox). See also Stephen, n 20, p 119.

${ }^{60}$ See also Jones $v$ Ashburnham (1804) 4 East 455 (102 ER 905) per Ellenborough CJ 'to seize a dead body upon such pretence [ie. for a debt] would be contra bonos mores, and an extortion upon the relatives.' See also Russell, n 3, vol 2, p 1420.

${ }^{61}$ They were sentenced to 3 years imprisonment.

${ }^{62}$ At $\mathrm{p} 98$.

${ }^{63}$ Russell, n 3, vol 2, p 1420.

${ }^{64}$ See $\mathrm{n} 57$ for $R v$ Young. See also Andrew v Cawthorne (1745) Willes 537 (125 ER 1308)(Court of Common Pleas). Russell (writing in 1819), n 19, p 607 stated in respect of this case: 'The refusal or neglect to bury dead bodies by those whose duty it is to perform the office, appears also to have been considered as a misdemeanour. Thus Abney J, in delivering the opinion of the court of common pleas, said 'The burial of the dead is, (as I apprehend,) the duty of every parochial priest and minister; and, if neglect or refuse to perform the office, he may, by the express words of the canon 86 . be suspended by the ordinary for three months. And if any temporal inconvenience arise, as a nuisance, from the neglect of the interment of the dead corpse, he is punishable also by the temporal courts, by indictment or information.' Russell states in a fn 'Abney, J cited a case H 7 G 1 BR [this is a reference to an unreported King's Bench case in Hilary Term, 1721] where that court made a rule upon the rector of Daventry, in Northamptonshire, to shew cause why an information should not be filed, because he neglected to bury a poor parishioner who died in that parish.'

${ }^{65} R$ v Skidmore [2009] Crim LR 42.
} 
exist.

\section{REMOVING A CORPSE FROM A GRAVE}

Various cases have held that it is an offence to remove a corpse from a grave, viz.

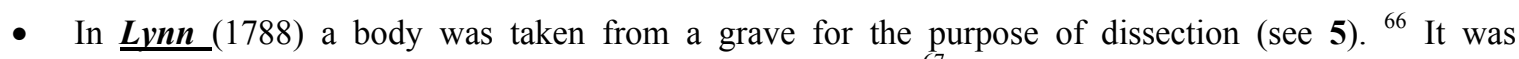
immaterial whether the body was disposed of for gain or not; ${ }^{67}$

- In Sharpe (1857) a corpse was taken from a grave in the burial ground of a congregation of Protestant dissenters. It was no defence that the motive of the defendant was pious and laudable (he was moving his mother's coffin to bury it in his father' grave in a churchyard some miles off). ${ }^{68}$ This offence was also punishable under the Burial Act 1857, s 25 (still extant) ${ }^{69}$

- In Kenyon (1901) it was stated to be a common law offence to unlawfully, unwillingly and indecently open graves. ${ }^{70}$ In this case the defendants - seeking to put up some buildings for their rope making business - dug up part of a closed catholic burial ground (it was closed in 1859), in Dukinfield (a town in Tameside, Greater Manchester). In so doing they dug up coffins and burnt them (it is unclear what they did with the bones. However, presumably they were also burnt). The defendant who was the principal offender was sentenced to 2 months prison and bound over in a recognizance of $£ 500$. He was also obliged to pull down the buildings and restore the ground.

In conclusion, these cases establish that unlawful removal of a corpse from a grave includes: (a) grave robbing (Lynn, Gilles, Duffin \& March), (b) a relative extracting it without consent (Sharpe), albeit with pious motives, (c) digging up bodies in a closed cemetery (Kenyon).

\section{OBSTRUCTING A CORONER'S INQUEST}

$R v$ Stephenson (1884) ${ }^{71}$ held that it was a misdemeanour at common law to burn - or otherwise dispose of - a corpse with intent to prevent the holding on such body of an intended coroner's inquest. Also, to obstruct a coroner in the execution of his duty in a case where the inquest was one which the coroner had jurisdiction to hold. Thus, Stephen J stated:

It is a misdemeanor to destroy a body upon which an inquisition is about to be properly held, with intent to prevent the holding of that inquest. ${ }^{72}$

It must be established there is a duty to hold an inquest; it is insufficient to prove the concealment of a corpse. Further, the intention must be proved as stated. ${ }^{73}$

\footnotetext{
${ }^{66}$ See also $R v$ Gilles (1820) R \& R 366n (168 ER 848). Also, Russell, $\mathrm{n} 3$, vol 2, pp 1415-6 'An indictment charged (inter alia) that the prisoner a certain dead body of a person unknown lately before deceased, wilfully, unlawfully and indecently did take and carry away with intent to sell and dispose of the same for gain and profit; and it being evident that the prisoner had taken the body from some burial ground, though from what particular place was uncertain, he was found guilty upon this count. And it was considered so clearly that this was an indictable offence that no case was reserved.' See also $R v$ Duffin \& Marsh (1818) R \& R 365 (168 ER 847)(grave robbing). For an early case see T Salmon, The Chronological Historian (London, $2^{\text {nd }}$ ed, 1733), p 391 (in 1717) 'Joseph Bowen, a grave digger, convicted of taking the corpse of one Chidders out of Bethlehem church yard and selling it to a surgeon ... fined forty shillings, and sentenced to be whipped from Newgate to Smithfield bar (spelling modernised).

${ }^{67} R v$ Cundick (1822) Dow \& Ry NP 13 (171 ER 900)(to sell the corpse of a capital convict for dissection, where the same was no part of the sentence, was a misdemeanour indictable at common law).

${ }^{68} R v$ Sharpe (1857) Dears \& B 160 (169 ER 959). Erle CJ stated at $\mathrm{p} 96$ 'The defendant was wrongfully in the burial ground, and wrongfully opened the grave, and took out several corpses [of family members] and carried away one. We say he did this wrongfully, that is to say, by trespass; for the licence which he obtained to enter and open, from the person who had the care of the place, was not given or intended for the purpose to which he applied it, and was, as to that purpose, no licence at all. The evidence for the prosecution proved the misdemeanor unless there was a defence.' See also Stephen, n 20, p 119, Harris, n 2, p 221 and Russell, n 3, vol 2, pp 1414-5.

${ }^{69}$ Section 25 provides that bodies are not to be removed from a burial ground, save under faculty without the licence of the Secretary of State. See also Polson, n 5, ch 19 (he mentions a case in 1960 of a (mentally ill) man removing a corpse (his mother) from a grave without lawful authority).

${ }^{70} R v$ Kenyon (1901) 36 LJ Newsp 571. See also $R v$ Tipping and Harris (Maidstone, Autumn Goal Delivery, 21 November 1908) referred to in A Denman, Digest of the Law, Practice and Procedure relating to Indictable Offences (Sweet \& Maxwell, 1912) (a parish sexton and gravedigger were indicted for unlawfully, wilfully and indecently opening a grave in a burial ground and removing the body. Charged as a common law nuisance. Sexton fined $£ 25$, gravedigger given 6 days imprisonment).

7113 QBD 331 (the body of an illegitimate infant was surreptitiously burnt with the intent to prevent the coroner from holding an inquest in respect of it). See also $R v$ Price (1884) 12 QBD 247, see n 22. Also, Russell, n 3, vol 2, pp 1421-2 and cases cited therein.

${ }^{72}$ At $\mathrm{p}$ 337. Also, $\mathrm{p} 338$ 'If a person destroys a dead body or moves it to prevent an inquest being held he is guilty of an offence if the inquest intended to be held was one that might lawfully be held.'

${ }^{73} R v$ Purcy (1933) $24 \mathrm{Cr}$ App R 70 (an indictment for obstructing a coroner in the execution of his duty to hold an inquest. The corpse of a baby was hidden in a hedge).
} 


\section{FORMULATION OF STEPHEN IN 1883}

The jurist Stephen - in his digest of the criminal law in 1883 - proposed an article 175 entitled 'Preventing the burial of dead bodies and disinterring them.' It stated: ${ }^{74}$

Every one commits a misdemeanour who prevents the burial of any dead body, or who, without authority, disinters a dead body ${ }^{75}$ even from laudable motives; ${ }^{76}$ or who having the means, neglects to bury a dead body which he is legally bound to bury, provided that no one is legally bound to incur a debt for such a purpose; ${ }^{77}$ [or] who buries or otherwise disposes of any dead body on which an inquest ought to be taken, without giving notice to a coroner, or who, being under a legal duty to do so, fails to give notice to a coroner that a body on which an inquest ought to be held is lying unburied, before such body has putrified. $^{78}$

This formulation, while useful for Victorian times, can be updated.

\section{OUTRAGING PUBLIC DECENCY}

In Gibson (1990) ${ }^{79}$ a work of art was displayed in a London art gallery, entitled 'Human Earrings.' These consisted of the head of a model which sported a pair of earrings, each of which were made out of a freeze dried human foetus of 3-4 months gestation, with a ring fitting tapped into its skull and attached at the other end to a model's earlobe. The art gallery was open to the public. Such an exhibition was held to constitute outraging public decency. However, it is asserted that, today, this would be better treated as being a crime relating to the unlawful treatment of a corpse. That is, unlawfully to fail to prevent the disposal of a corpse.

\section{NEW OFFENCE - UNLAWFUL TREATMENT OF A CORPSE}

Having considered the above, it is asserted there should be a statutory offence which covers all the above crimes. One of 'Unlawful Treatment of a Corpse'. A 'corpse' would be defined to comprise a human body, including any foetus or embryo. ${ }^{80}$ Thus, it should be an offence for a person, unlawfully, to:

(a) fail to dispose of a corpse, when responsible for the same;

(b) prevent the disposal of a corpse;

(c) remove ${ }^{81}$ a corpse from a grave; ${ }^{82}$

(d) open a grave; ${ }^{83}$

(e) dispose of a corpse, in order to obstruct, or prevent, an inquest by a coroner in respect of the same. ${ }^{84}$

All these should be unlawful whether undertaken for profit or not. As to the lawful disposal of a corpse, the section should also provide that it may be disposed of by way of:

(a) burial; ${ }^{85}$

(b) cremation in a crematorium to which the Cremation Act 1902 applies, in the case where the

\footnotetext{
${ }^{74}$ See Stephen, n 20, p 118.

${ }^{75}$ By way of example, he cites Lynn, see 5. It may be noted that early English law held the desecration of a grave to be heinous meriting severe punishment. See LJ Downer, Leges Henrici Primi (c. 1115), p 261 'If anyone dares to dig up or despoil, in a scandalous and criminal fashion, a body buried in the ground or in a coffin or a rock or a pyramid or any structure, he shall be regarded as an outlaw.'

${ }^{76}$ In a fn he cites Vann, see 4.

77 By way of example he cites Sharpe, see $\mathbf{6}$ and Scott, see $\mathbf{5}$.

${ }^{78}$ He refers to Russell, vol 1, p $620\left(5^{\text {th }}\right.$ ed, 1877) and the $7^{\text {th }}$ Report of the Criminal Law Commissioners, pp 50, 51.

${ }^{79} R v$ Gibson, $R v$ Sylveine [1990] 2 QB 619.

80 'Corpse' would seem more apposite (and shorter) than the words 'dead body.'

${ }^{81}$ Older words are 'dis-inter' or 'exhume.' However, 'remove' would seem more in keeping with modern language usage.

82 (c) would cover grave robbing for dissection or other purposes, see Lynn (dissection), see 5. Also, whether the body was removed for profit (see $R v$ Kenyon, see $\mathbf{6}$ (to develop a business), or not (the latter to include pious motives, as in Sharpe, see 6). It would not include lawful removal, such as, see MOJ-2007, n 5, para 15 (a) in the interests of justice (for example, exhumation on the order of a coroner); (b) for personal reasons by the next of kin of the deceased; (c) on the grounds of public health or nuisance; (d) in the public interest (in connection with site developments which have public or other planning consent); (e) for scientific purposes (eg. for archaeological research); (f) for other exceptional reasons (for the re-use of the grave etc).

${ }^{83}$ This would cover where the body is not actually removed, but the grave was opened, for example, for sight-seeing..

${ }^{84}$ This would cover Stephenson, see 7.

${ }^{85}$ This would include burial at sea. See also Polson, n 5, p 55 (formerly governed by the Burial of Drowned Persons Acts 1808 and 1883 , replaced by the National Assistance Act 1948, s 50).
} 
deceased has previously agreed to, or not expressly prohibited, the same; ${ }^{86}$

(c) donation pursuant to the Human Tissue Act 2004, ${ }^{87}$

(d) such other manner as otherwise previously specified by the deceased in writing which is witnessed and where a coroner permits having regard to health considerations, as well as those of public decency. ${ }^{88}$

As to the person responsible for the disposal of a corpse, ${ }^{89}$ the section should provide that such person comprises the following, the:

(a) executor, if sufficient funds are available from the estate of the deceased $;^{90}$

failing which the,

(b) husband or wife, in the case of a spouse; or ${ }^{91}$

(c) father or mother, in the case of an unmarried child; or $^{92}$

(d) any brother or sister, in the absence of (a)-(c);

failing which,

(e) as provided in the present Public Health (Control of Disease) Act 1984.

The latter Act, s 46 (entitled 'burial and cremation') provides, inter alia:

(1) It shall be the duty of a local authority to cause to be buried or cremated the body of any person who has died or been found dead in their area, in any case where it appears to the authority that not suitable arrangements for the disposal of the body have been or are being made otherwise than by the authority;

(2) Any council which is the local authority for the purposes of the Local Authority Social Services Act 1970 may cause to be buried or cremated the body of any deceased person who immediately before his death was being provided with accommodation under Part III of the National Assistance Act 1948 by, or by arrangement with, the council or was living in a hostel provided by the council under section 29 of that Act. ${ }^{93}$

In respect of these the legislation also provides that:

- An authority shall not cause a body to be cremated under these sub-sections where it has reason to believe that cremation would be contrary to the wishes of the deceased; ${ }^{94}$

\footnotetext{
${ }^{86}$ As to cremation being contrary to the wishes of the deceased in respect of the Public Health (Control of Disease) Act 1984, s n 94. As to the general obligation of an executor to accord with a testator's wishes see Polson, n 5, p 57 'It is not unusual for a testator to include directions in his will for the disposal of his body after death. In general, these are not binding upon his executor or relatives and, except in the circumstances discussed below [he discusses them on $\mathrm{p} 58$ of the same] such directions may be completely disregarded.' As authority for his statement, Polson refers to Sharpe, see n 68.

${ }^{87}$ Ibid.

${ }^{88}$ In the US and USSR, cryonics (the low temperature preservation of corpses) is legally permitted. However, it appears it is not permitted in France (which only permits burial, cremation and medical donation). As for the UK, providing a person gives prior consent and the facilities do not pose a risk to human health or decency - one would have thought that it should be permitted. See also Polson, n 5, pp 40-1 (cryonic disposal).

${ }^{89}$ See MOJ-2007, n 5, para 10 'The Government believes that there would be benefits in making clearer the responsibilities of the family and/or the executor of the estate of the deceased, although further work would be required to determine what those responsibilities should be and how they might be enforced.'

${ }^{90}$ See Russell, $n$ 49. See also Polson, n 5, pp 49-51. At p 49 'It is the duty of the executor to dispose of the remains of the deceased in a manner suitable to the estate he has left behind. He may not be lavish in this at the expense of creditors or beneficiaries, without their consent. In the event that the amount of the funeral expenses be contested as extravagant, the court will determine what would have been reasonable in the circumstances.' Also, p 50 'The executor is personally responsible for funeral expenses, but he is entitled to reimburse himself out of the estate of all reasonable expenses properly incurred in the execution of his trust.' He cites Rees v Hughes [1946] KB 517.

${ }^{91}$ See also Polson, n 5, pp 51-2. Cf. Rees v Hughes [1946] KB 517 (a married women is treated as a feme sole and so the obligation falls on her estate). However, this case removed an anomaly (in Victorian times the husband was responsible in law for the wife). Today, with sexual equality, it is appropriate that the husband or wife be responsible for the other partner, not least to prevent the taxpayer having to pick up the bill.

92 This covers Vann where the court held that a 'man is bound to give Christian burial to his deceased child.' Today, with sexual equality, the mother should also be responsible.

${ }^{93}$ For the position prior to this, see Polson, n 5, p 48 and National Assistance Act 1948, s 50 (rep). See also the Public Health (Control of Diseases) Act 1984, s 48 (removal of body to mortuary or for immediate burial).

${ }^{94}$ Section 46(3).
} 
- The sub-sections do not affect any enactment regulating (or authorising) the burial, cremation or anatomical examination of the body of a deceased person; ${ }^{95}$

- An authority may recover from the estate of the deceased person (or from any person who for the purposes of the National Assistance Act 1948 was liable to maintain the deceased person immediately before his death) expenses incurred under the sub-sections. ${ }^{96}$

- Without prejudice to any other method of recovery, a sum due to an authority under ss (5) is recoverable summarily as a civil debt by proceedings brought within 3 years after the sum becomes due. ${ }^{97}$

In conclusion, the merit of specifying who is responsible for the disposal of a corpse is that it will clarify the law. This will reduce potential litigation as well as save the tax-payer much money since the latter should only be responsible for the disposal of corpses as a 'last' resort.

\section{BURIAL ACTS}

There are a number of pieces of legislation extant which relate to cemeteries and burial: ${ }^{98}$

- Burial Acts 1852, 1853, 1855, 1857, 1859 and the Burial Amendment Act 1880;

- Cemeteries Clauses Act 1847 and the Cemeteries Acts 1902 and 1952;

- Disused Burial Grounds Act 1884 and the Disused Burial Grounds (Amendment) Act 1981;

- Registration of Burials Act 1864.

It would be very useful for all these to now be consolidated into one Act ${ }^{99}$ and for the new statutory offence in 10 to be inserted into the same.

\section{Copyrights}

Copyright for this article is retained by the author(s), with first publication rights granted to the journal.

This is an open-access article distributed under the terms and conditions of the Creative Commons Attribution license (http://creativecommons.org/licenses/by/3.0/).

\footnotetext{
95 Ibid, ss (4).

96 Ibid, ss (5).

${ }^{97}$ Ibid, ss (6).

${ }^{98}$ See generally Halsbury, Statutes (4 $4^{\text {th }}$ ed, with updates), vol 5. See also Ministry of Justice, Burial Grounds: The Result of a Survey of Burial Grounds in England and Wales (2007) and Ministry of Justice, Burials: The Results of a Survey of Burial Grounds in England and Wales (16 Feb 2012). See also MOJ-2007, n 5.

${ }^{99}$ Given that cremation is now so popular and this is likely to increase, then it would seem useful to place provisions on cremation at the beginning of the Act (not least since - given the general trend towards cremation - it is likely that $85 \%$ of persons in the UK will opt for this within the next 10-15 years).
} 